\title{
Immunogold localization of the DnaK heat shock protein in Escherichia coli cells
}

\author{
Bernd Bukau, ${ }^{1 *}$ Pat Reilly, ${ }^{2}$ John McCarty ${ }^{1}$ and Graham C. Walker ${ }^{2}$ \\ 'Zentrum für Molekulare Biologie, Universität Heidelberg, INF 282, D6900 Heidelberg, FRG \\ ${ }^{2}$ Biology Department, Massachusetts Institute of Technology, Cambridge, MA 02139, USA
}

(Received 28 May 1992; revised 19 August 1992; accepted 14 September 1992)

\begin{abstract}
Previously reported cell fractionation experiments have yielded conflicting information on the cellular localization of the DnaK heat shock protein of Escherichia coli. Here we used immunogold labelling of ultra-thin sections to determine the localization of DnaK in unstressed cells at $30^{\circ} \mathrm{C}$ as well as in heat-shocked cells. In cells grown at $30{ }^{\circ} \mathrm{C}$, gold particles were found predominantly in the cytoplasm, indicating that the majority of the DnaK molecules are cytoplasmic; however, a fraction of the gold particles was located in proximity to the membranes, raising the possibility that a subpopulation of DnaK proteins is membrane-associated. Heat shock of the cells did not induce detectable relocalization of DnaK.
\end{abstract}

\section{Introduction}

The DnaK heat shock protein of Escherichia coli is a member of the ubiquitous Hsp70 protein family that has been highly conserved during evolution (Bardwell \& Craig, 1984). Hsp 70 proteins are molecular chaperones that catalyse protein folding as well as disassembly of oligomeric protein complexes (Morimoto et al., 1990; Gething \& Sambrook, 1992). In eukaryotes, this chaperone function appears to be required within multiple cellular compartments since Hsp 70 proteins are found in the mitochondria, chloroplasts, endoplasmatic reticuli, nuclei and cytoplasm of several types of eukaryotic cells (Morimoto et al., 1990; Gething \& Sambrook, 1992). Furthermore, in Drosophila, cytoplasmic Hsp70 proteins relocalize upon heat shock and migrate to the nucleus (Morimoto et al., 1990), suggesting stress-induced changes in their cellular functions. In E. coli, conflicting data exist on the localization of DnaK in unstressed cells, while no information is available on its localization in heat-shocked cells. In minicells infected with lambda phages encoding the $d n a K^{+}$gene, DnaK was predominantly found in the membrane fraction (Zylicz $e t$ al., 1983). Consistent with this result it has been shown that DnaK cofractionates with the inner membrane fraction of minicells (Kostyal et al., 1989). In another study, it was reported that DnaK was not only associated

* Author for correspondence. Tel. 496221566865 ; fax 496221 565892 . with membrane fractions but was also present in significant amounts in the soluble fractions of wild-type cells (Bardwell et al., 1986). It is unclear whether the apparent association of DnaK with membrane fractions reflects a physiologically significant state or is an artifact of the cell lysis procedure. In fact, cell fractionation experiments have been shown to yield artifactual results with respect to the localization of hybrid proteins (Tommassen et al., 1985). DnaK might be particularly prone to artifactual association with membranes during cell fractionation since, as a chaperone, it is capable of hydrophobic protein-protein interactions (Liberek et al., 1988). Furthermore, non-esterified fatty acids are bound to Hsp70 of rat cells (Guidon \& Hightower, 1986), which raises the possibility that Hsp70 proteins in general exhibit affinities to membrane fractions. In these experiments we used immunogold labelling of thin sections of E. coli cells to examine the cellular localization of DnaK in unstressed cells and to establish whether heat-shockinduced relocalization occurs.

\section{Methods}

Generation of DnaK-specific antiserum. We purified DnaK according to standard procedures (Schlossman et al., 1984) from cells overproducing DnaK due to the presence of the multicopy plasmid pBBI, which encodes the dnaKJ operon (unpublished data). DnaK was further gel-purified and injected into rabbits. The polyclonal antiserum was specific for DnaK but cross-reacted with other cellular proteins in dna $K^{+}$and $\Delta d$ naK52 cells (Fig. 1, lanes 1 and 2). In order to eliminate cross-reactivity we first absorbed the antiserum to a Sepharose column 


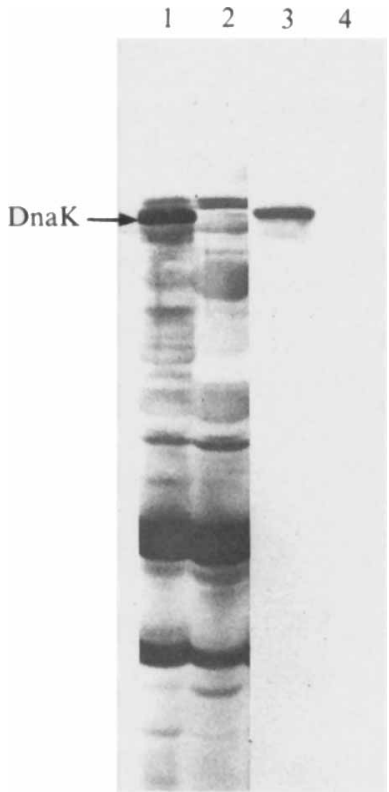

Fig. 1. Specificity of antisera raised against DnaK. The specificity of a polyclonal rabbit antiserum raised against purified DnaK (lanes 1 and 2), and of DnaK-specific antibodies obtained by affinity purification of this serum (lanes 3 and 4), was tested by immunoblots using total cell extracts of wild-type cells (lanes 1 and 3 ) and of $\Delta d n a K 52$ cells (lanes 2 and 4). The position of DnaK is indicated.

which had total cellular extracts of $\Delta d$ dnaK52 mutants covalently linked to it, then purified DnaK-specific antibodies by affinity chromatography with DnaK covalently linked to Sepharose. The resulting antiserum was very specific for DnaK and eliminated most crossreactivity with other cellular proteins in $d n a K^{+}$and $\Delta d n a K 52$ cells (Fig. 1 , lanes 3 and 4).

Preparation of cells for immunogold staining. Cells of $E$. coli strains $\mathrm{AB} 1157\left(\mathrm{~F}^{-}\right.$thr-1 leu-6 proA2 his-4 thi-1 argE3 lac Y1 galK2 ara-14 $x y l-$ 5 mtl-1 tsx-33 supE37) and GW4813 (AB1157 $\Delta$ dnaK52:: $\mathrm{Cm}^{\mathrm{r}}$ ) (Paek \& Walker, 1987) were grown at $30^{\circ} \mathrm{C}$ in $\mathrm{M} 9$ minimal medium (Miller, 1972) supplemented with appropriate amino acids $\left(50 \mu \mathrm{g} \mathrm{ml}^{-1}\right)$, thiamin $(0.001 \%)$, and glucose $(0.2 \%)$. Aliquots $(2.5 \mathrm{ml})$ of exponentially growing cells $\left(\mathrm{OD}_{600}=0.5\right)$ were either incubated for $15 \mathrm{~min}$ at $43.5^{\circ} \mathrm{C}$ or left at $30^{\circ} \mathrm{C}$, and then subjected to the fixation procedure.
Immunogold staining. Cells of strains AB1157 and GW4813 grown at $30^{\circ} \mathrm{C}$ were fixed according to Francesconi et al. (1988) with modifications as follows. Cells were centrifuged for $2 \mathrm{~min}$, immediately resuspended in $1.5 \mathrm{ml}$ fixation mixture $(2 \%, \mathrm{v} / \mathrm{v}$, paraformaldehyde. $0 \cdot 1 \%$ glutaraldehyde, $100 \mathrm{~mm}$-cacodylate buffer $\mathrm{pH} 7 \cdot 2$ ), and incubated at room temperature $\left(30^{\circ} \mathrm{C}\right.$ probes) or at $43.5^{\circ} \mathrm{C}$ (heat-shocked probes) for $1 \mathrm{~h}$, then at $4{ }^{\circ} \mathrm{C}$ for $5 \mathrm{~h}$. The supernatant was withdrawn, replaced with $0.5 \mathrm{M}-\mathrm{NH}_{4} \mathrm{Cl}(0.3 \mathrm{ml})$ and further incubated overnight. The cell pellet was dehydrated (Francesconi et al., 1988) and embedded in Lowicryl K4M followed by UV polymerization (Simon et al., 1987) according to standard procedures. Blocks $\left(1 \mathrm{~mm}^{2}\right)$ of $90 \mathrm{~nm}$ thickness were prepared and placed on 200 -mesh nickel grids. For immunostaining, the grids were incubated for $20 \mathrm{~min}$ at room temperature in blocking buffer (phosphate-buffered saline, sodium azide, bovine serum albumin; EY Labs, Inc.), followed by overnight incubation at $4{ }^{\circ} \mathrm{C}$ with a 1:10 dilution of an anti-DnaK polyclonal antibody solution. After incubation with primary antibodies, the grids were rinsed six times for $10 \mathrm{~min}$ in blocking buffer and incubated for $60 \mathrm{~min}$ at room temperature with a $1: 2$ dilution of secondary antibodies (goat-antirabbit antibodies with covalently linked gold particles of $10 \mathrm{~nm}$ diameter; EY Labs, Inc.). The grids were rinsed three times for $10 \mathrm{~min}$ in blocking buffer and twice for $10 \mathrm{~min}$ in $\mathrm{H}_{2} \mathrm{O}$, followed by incubation in osmium tetroxide $(2 \%, \mathrm{w} / \mathrm{v})$ for $2 \mathrm{~min}$. After rinsing three times for $5 \mathrm{~min}$ in $\mathrm{H}_{2} \mathrm{O}$ the specimens were post-stained in a saturated solution of uranyl acetate $(5 \mathrm{~min})$ and Reynold's lead citrate $(2 \mathrm{~min})$. The samples were analysed at $80 \mathrm{kv}$ in a JEOL 100B electron microscope.

\section{Results and Discussion}

An important requirement for our approach of using immunogold labelling to analyse the cellular localization of DnaK in $E$. coli cells was the availability of dnaK null mutants to serve as negative controls. We have recently reported the isolation and characterization of $\Delta$ dnaK52:: $\mathrm{Cm}^{\mathrm{r}}$ mutants which completely lack DnaK (Bukau \& Walker, 1989a,b; 1990; Paek \& Walker, 1987). Wild-type (AB1157) and $\Delta d n a K 52:: \mathrm{Cm}^{\mathrm{r}}$ mutant (GW4813) cells were grown at $30^{\circ} \mathrm{C}$ and either subjected to a heat shock at $43.5^{\circ} \mathrm{C}$ or left at $30^{\circ} \mathrm{C}$. Cells were fixed and incubated with a purified anti-DnaK polyclonal antibody solution that was highly specific for DnaK
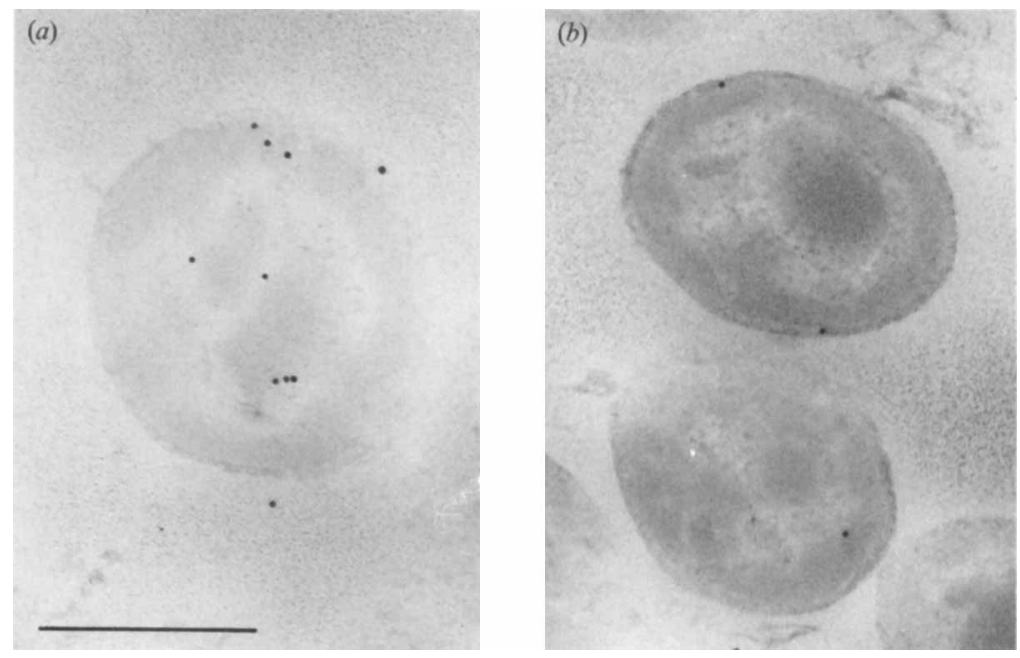

Fig. 2. Immunogold staining of wild-type and $\Delta d n a K 52$ mutant cells at $30^{\circ} \mathrm{C}$. Ultrathin sections of cells of strains $\mathrm{AB} 1157\left(\right.$ dnaK $\left.^{+}\right)(a)$ and GW4813 (AdnaK52) (b) grown at $30^{\circ} \mathrm{C}$ were immunogold labelled using DnaK-specific antibodies and analysed by electron microscopy, as described in Methods. Bar, $0.5 \mu \mathrm{m}$. 

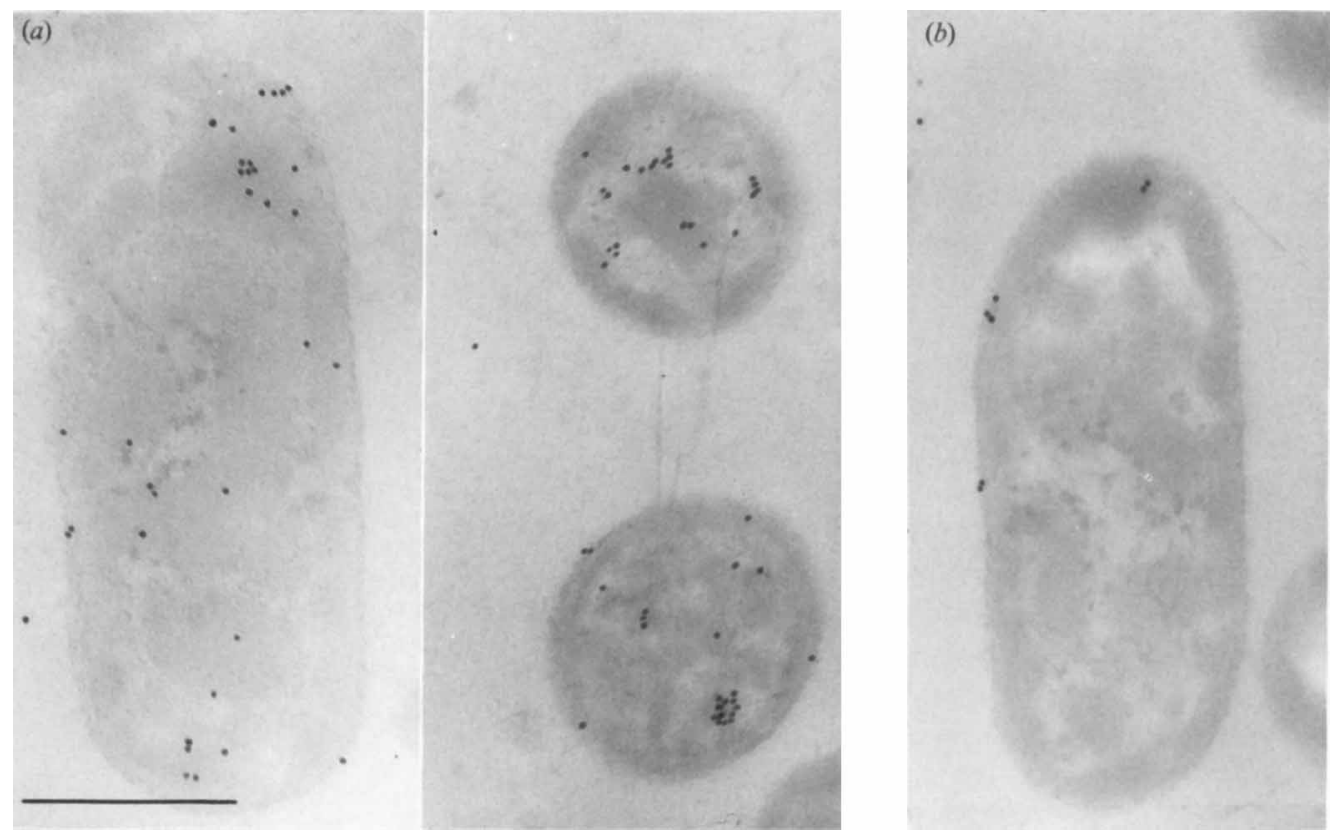

Fig. 3. Immunogold staining of wild-type and $\Delta d n a K 52$ mutant cells after heat shock. Cells of strains $\mathrm{AB} 1157\left(\right.$ dnaK $\left.K^{+}\right)(a)$ and $\mathrm{GW} 4813$ $\left(\Delta d\right.$ naK52) $(b)$ grown at $30^{\circ} \mathrm{C}$ were shifted to $43.5^{\circ} \mathrm{C}$ for $15 \mathrm{~min}$ and ultrathin sections were prepared for immunogold labelling as described in Methods. Bar, $0.5 \mu \mathrm{m}$.

Table 1. Gold particle counts of E. coli cells immunolabelled with DnaK-specific antibodies

\begin{tabular}{|c|c|c|c|c|}
\hline & \multicolumn{2}{|c|}{$30^{\circ} \mathrm{C}$} & \multicolumn{2}{|c|}{$42^{\circ} \mathrm{C}$} \\
\hline & Wild-type & $\Delta d n a K 52$ & Wild-type & $\Delta d n a K 52$ \\
\hline No. of cells* & 31 & 66 & 72 & 45 \\
\hline Gold particles in cells $†$ & 222 & 182 & 1110 & 191 \\
\hline Gold particles in cells/gold particles in background $\ddagger$ & $5 \cdot 3$ & 1.4 & $7 \cdot 1$ & $1 \cdot 2$ \\
\hline Gold particles per cells & $7 \cdot 16(6.63)$ & $2 \cdot 76(3.96)$ & $15.4(14.84)$ & $4.24(5.99)$ \\
\hline Gold particles in cytoplasm per cell $\|$ & $5.42(5 \cdot 75)$ & $1.89(3 \cdot 31)$ & $12 \cdot 46(13.08)$ & $2.69(5 \cdot 36)$ \\
\hline Gold particles at membranes per cellq & $1.74(2.38)$ & $0.86(1.34)$ & $2 \cdot 95(4 \cdot 14)$ & $1 \cdot 56(2 \cdot 42)$ \\
\hline Gold particles at membranes ( $\%$ of total) & $24 \cdot 3$ & $31 \cdot 3$ & $19 \cdot 2$ & $36 \cdot 2$ \\
\hline
\end{tabular}

* All cells that were in focus on the photographs were analysed unless the cell envelope was disrupted or not detectable.

$\dagger$ Numbers represent the total of gold particles present in the cells analysed. All gold particles were considered which were located within the cells or outside the cells up to a distance of two gold particles from the membranes. This distance corresponds approximately to the maximal theoretical distance $(20 \mathrm{~nm} \times$ magnification) that a gold particle can be away from its primary antibody bound to a membrane-associated antigen.

$\ddagger$ For each analysed cell, gold particles present in a cell-free area of identical size and shape were counted as described in the preceding footnote. Cell-free areas were chosen that were adjacent to the corresponding cell at its right side or, if no cell-free area was present at this location, at the next cell-free location adjacent to the cell counterclockwise from its right side.

$\S$ The standard deviation $(\sigma n)$ is given in parentheses.

|| Gold particles located within the cytoplasm of the cells up to a distance of two gold particles from the inside of the membranes were considered as cytoplasmic. The standard deviation $(\sigma n)$ is given in parentheses.

- Gold particles located at the membranes or up to two gold particles away from either side of the membranes were considered as membraneassociated. The standard deviation $(\sigma n)$ is given in parentheses.

(Fig. 1). After incubation with primary antibody, the cells were incubated with gold-labelled secondary antibodies and analysed microscopically.

The results of our localization study are shown in Figs. 2 and 3, and Table 1. The number of gold particles present within wild-type cells was well above $(5 \cdot 3$-fold for unstressed cells; $7 \cdot 1$-fold for heat-shocked cells) the number of gold particles present within a comparable area of background. In contrast, the number of gold particles present within $\Delta$ dnaK52 control cells was only slightly (1.4-fold and 1.2-fold) above background. The slight increase in the number of gold particles within $\Delta d n a K 52$ cells as compared to background might be due to cross-reactivity of the antibodies with cellular proteins other than DnaK which was not eliminated by purification of the anti-DnaK serum used here (see below). The results show that the immunogold labelling of wild-type cells is highly specific for DnaK. 
In wild-type cells grown at $30^{\circ} \mathrm{C}$, the majority of the gold particles were located within the cytoplasm, indicating that DnaK is mostly cytoplasmic. We searched for clustering of gold particles within specific regions of the cytoplasm and especially within nucleoid structures, given that $\Delta d n a K 52$ mutants possess severe defects in chromosome segregation (Bukau \& Walker, 1989b), suggesting a direct or indirect role of $\mathrm{DnaK}$ in processes that are required for proper chromosome distribution. However, we did not observe significant clustering of gold particles within specific regions of the cytoplasm.

A significant subpopulation of gold particles was, however, located at or near the cell membranes, raising the possibility that a fraction of DnaK might be membrane-associated. Based on our studies we estimate that the maximum amount of DnaK that could possibly be membrane-associated is $24 \%$ of total DnaK (Table 1). This observed concentration of gold particles near the membrane, however, is also that predicted if there were no significant association of DnaK with the membrane. The estimate of maximum percentage of DnaK associated with the membrane was arrived at by calculating the percentage of cell-associated gold particles that were within two gold particles of the membranes. This distance corresponds approximately to the maximum theoretical distance that a gold particle could be from the membrane if its primary antibody was bound to a membrane-associated antigen and results in an area that is $20-30 \%$ of the total cellular area (depending on the orientation of the section). Therefore, for a given cytoplasmic protein, approximately $20-30 \%$ would be predicted to label with gold particles in a manner indistinguishable from that of a membraneasssociated protein. Since this percentage is in the range of what was observed for DnaK, the percentage of DnaK molecules that is membrane-associated is probably significantly less than the maximum of $24 \%$ and allows the possibility that there is no significant localization of DnaK to the membrane at all. Finally, cross-reactivity to membrane-associated proteins other than DnaK might also contribute to a potential overestimation of the association of DnaK with the membrane. It has been reported that a region of the $E$. coli MOB2 membrane protein has significant homology to DnaK (Jacq et al., 1989). Cross-reactivity to MOB2 might have remained undetected in the Western blot shown in Fig. 1 because of the small molecular mass $(10 \mathrm{kDa})$ of MOB2. Taken together, our data do not support conclusions derived from cell-fractionation experiments that $\mathrm{DnaK}$ is largely membrane-associated in intact cells of $E$. coli.

In wild-type cells subjected to heat shock the number of gold particles per cell was more than twofold greater than in unstressed wild-type cells. The distribution of gold particles was similar to that in unstressed cells.
Thus, after heat shock the majority of DnaK molecules remain cytoplasmic and only a subfraction (up to $19 \%$ ) of DnaK proteins might be membrane-associated. We found no indication of major stress-induced relocalization of DnaK.

In summary, our results indicate a predominantly cytoplasmic localization of DnaK in both unstressed and heat-shocked cells which suggests that the majority of the cellular processes that require chaperone functions of DnaK are cytoplasmic.

We thank J. King for helpful discussions, advice and support throughout this work. We are grateful to S. Penman and F. Solomon for helpful discussions, and to J. McNeil and R. Singer for use of the morphometer. This research was supported by Public Health Service grant GM28988 from the National Institute of General Medical Sciences. B.B. was supported by a fellowship of the Deutscher Akademischer Austauschdienst.

\section{References}

BardWell, J. C. A. \& Craig, E. A. (1984). Major heat shock gene of Drosophila and the Escherichia coli heat-inducible dnaK gene are homologous. Proceedings of the National Academy of Sciences of the United States of America 81, 848-852.

Bardwell, J. C. A., Tilly, K., Craig, E., King, J., Zyluyz, M. \& Georgopoulos, C. (1986). The nucleotide sequence of the Escherichia coli K12 dnaJ ${ }^{+}$gene. Journal of Biological Chemistry 261, 1782-1785

Bukau, B. \& Walker, G. C. $(1989 a)$. Cellular defects caused by deletion of the Escherichia coli dnaK gene indicate roles for heat shock protein in normal metabolism. Journal of Bacteriology 171. 2337-2346

BUKAU, B. \& WALKER, G. C. $(1989 b)$. $\Delta d n a K 52$ mutants of Escherichia coli have defects in chromosome segregation and plasmid maintenance at normal growth temperatures. Journal of Bacteriology 171 , 6030-6038

BukaU, B. \& WALKer, G. C. (1990). Mutations altering heat shock specific subunit of RNA polymerase suppress major cellular defects of $E$. coli mutants lacking the DnaK chaperone. EMBO Journal 9. 4027-4036.

Francesconi, S. C., MacAlister, T. J., Setlow, B. \& Setlow, P. (1988). Immunoelectron microscopic localization of small, acidsoluble spore proteins in sporulating cells of Bacillus subtilis. Journal of Bacteriology 170, 5963-5967.

GethING, M.-J. \& SAMBrook, J. (1992). Protein folding in the cell Nature, London 355, 33-45.

Guidon, P. T. JR \& Hightower, L. E. (1986). Purification and initial characterization of the 71-kilodalton rat heat-shock protein and its cognate as fatty acid binding proteins. Biochemistry 25, 3231-3239.

JacQ, A., Kern, R., Tsugita, A. \& Kohiyama, M. (1989). Purification and characterization of a low-molecular-weight membrane protein with affinity for the Escherichia coli origin of replication. Journal of Bacteriology 171, 1409-1416.

Kostyal, D. A., Farrell, M., McCabe, A., Mei, Z. \& Firshein, W. (1989). Replication of an RK2 miniplasmid derivative in vitro by a DNA/membrane complex extracted from Escherichia coli: involvement of the $d n a A$ but not dnaK host proteins and association of these and plasmid-encoded proteins with the inner membrane. Plasmid $\mathbf{2 1}$. 226-237.

Liberek, K., Georgopoulos, C. \& Zylicz, M. (1988). Role of the Escherichia coli DnaK and DnaJ heat shock proteins in the initiation of bacteriophage $\lambda$ DNA replication. Proceedings of the National Academy of Sciences of the United States of America 85, 6632-6636.

Miller, J. H. (1972). Experiments in Molecular Genetics. Cold Spring Harbor, NY: Cold Spring Harbor Laboratory,

Morimoto, R. I., Tissieres, A. \& GeORGOPOUlos, C. (editors). (1990). 
Stress Proteins in Biology and Medicine (Cold Spring Harbor monograph Series Vol. 19). Cold Spring Harbor, NY: Cold Spring Harbor Laboratory.

PAEK, K.-H. \& WAlker, G. C. (1987). Escherichia coli dnaK nul mutants are inviable at high temperature. Journal of Bacteriology 169, 283-290.

Schlossman, D. M., Schmid, S. L., Braell, W. A. \& Rothman, J. E. (1984). An enzyme that removes clathrin coats: purification of an uncoating ATPase. Journal of Cellular Biology 99, 723-733.

Simon, G. T., Thomas, J. A., Chorneyko, K. A. \& Carlemalm, E.
(1987). Rapid embedding in Lowicryl K4M for immunoelectron microscopic studies. Journal of Electron Microscopical Techniques 6 , 317-324.

Tommassen, J., Leunissen, J., van Damme-Jongsten, M. \& Overduin, P. (1985). Failure of E. coli $\mathrm{K}-12$ to transport PhoE-LacZ hybrid proteins out of the cytoplasm. EMBO Journal 4, 1041-1047.

Zylicz, M., NieradKo, J. \& TAYlor, K. (1983). Escherichia coli dnaJand $d n a K$-gene products: synthesis in minicells and membraneaffinity. Biochemical and Biophysical Research Communications 110. 176-180. 